\title{
DESALINATION OF CHITOOLIGOSACCHARIDES USING GEL FILTRATION AND ULTRAFILTRATION
}

\section{Desalinasi Kitooligosakarida Menggunakan Teknik Kromatografi Filtrasi Gel dan Dialisis}

\author{
Pujoyuwono Martosuyono ${ }^{1 *}$, Asri Pratitis ${ }^{1}$, Alexander Prasetya ${ }^{2}$ and Elisabeth Kartika Prabawati ${ }^{2}$ \\ ${ }^{1}$ Research and Development Center for Marine and Fisheries Product Processing and Biotechnology, \\ Jl. K.S Tubun Petamburan VI, Central Jakarta, Indonesia, 10260 \\ 2. Department of Food Technology, Swiss German University, EduTown BSD City, Tangerang, Indonesia, 15339. \\ *Correspondence Author: pujo_yuwono@yahoo.com.au \\ Article history: \\ Received: 2 Juni 2014; Revised: 8 Oktober 2014; Accepted: 15 November 2014
}

\begin{abstract}
Chitooligosaccharide (COS), which is a derivative product from chitosan, has recently been used as a functional food because it has antimicrobial, antifungal, and antitumor properties. The salt content in chitooligosaccharide is one of the main problems in application as functional food or pharmaceutical medicine. The aim of this study was to remove salt from COS with two desalting techniques and determine the variation of COSs in the product. The desalting technique used were dialysis with 10kD Molecular Weight Cut Off (MWCO) and gel filtration chromatography HiPrep 26/10 desalting with G-25 Superfine Sephadex as stationary phase in the column. In order to detect the presence of COS, Thin Layer Chromatography (TLC) method was used, followed by Matrix-Assisted Laser Desorption-Ionization Time-of-Flight Mass Spectrometry (MALDI-TOF-MS) to detect low concentration of COS. Qualitative and quantitative analysis of salt presence were identified using silver nitrate and Volhard method respectively. Ash content was measured using gravimetric method. Results showed those dialysis and gel filtration chromatographies were successfully remove the most of the salt from COS with efficiency of desalting up to $100 \%$. However, the best desalting technique was gel filtration chromatography HiPrep 26/10 which has more complete COS with various degrees of polymerization present in the result.
\end{abstract}

Keywords: chitooligosaccharide, desalting technique, dialysis, gel filtration chromatography

\section{ABSTRAK}

Kitooligosakarida merupakan produk turunan dari kitosan yang digunakan sebagai pangan fungsional karena memiliki sifat sebagai antimikroba, anti jamur dan anti tumor. Salah satu masalah utama penggunaan kitooligosakarida sebagai pangan fungsional atau bahan farmasetika adalah kandungan garam yang tinggi. Tujuan dari penelitian ini adalah untuk mempelajari teknik penghilangan garam (desalinasi) menggunakan teknik dialisis dan kromatografi filtrasi gel serta mempelajari keragaman produk oligomernya. Teknik dialisis dilakukan menggunakan membran dengan ambang batas bobot molekul (MWCO) 10kD dan kromatografi filtrasi gel menggunakan HiPrep 26/10 dengan kolom G-25 Sephadex Superfine. Untuk mendeteksi keberadaan produk kitooligosakarida, digunakan metode kromatografi lapis tipis (KLT) dan Matrix-Assisted Laser Desorption-Ionization Time-of-Flight Mass Spectrometry (MALDI-TOF-MS). Metode perak nitrat dan Volhard digunakan untuk menganalisis kandungan garam secara kualitiatif dan kuantitatif. Kandungan abu dalam produk kitooligosakarida dianalisis menggunakan teknik gravimetri. Hasil analisis menunjukkan bahwa teknik dialisis dan kromatografi filtrasi gel mampu menghilangkan kandungan garam dengan efisiensi mencapai 100\%. Teknik terbaik ditunjukkan oleh kromatografi filtrasi gel karena keragaman produk oligomer yang dihasilkan lebih tinggi dibandingkan teknik dialisis.

Kata Kunci: kitooligosakarida, teknik desalinasi, dialisis, kromatografi filtrasi gel

Permalink/DOI: http://10.15578/squalen.v9i3.110

\section{Introduction}

Indonesia produces approximately 235,000 tons of shrimp, of which $30 \%$ of them are the waste consisting of head and exoskeleton (Siringoringo, 2011). The unprocessed shrimp wastes produce an unpleasant smell and interfere with environmental sustainability (Mahata et al., 2008). Utilization of 
shrimp waste into economically and functionally valuable products reduces the environmental contamination as well as increasing its economic value.

Chitooligosaccharide (COS) is a derivative product from chitosan extracted from the exoskeleton of shrimp, crab, and other crustacean (Kim, 2011). Shrimp waste can be utilized for the production of chitin, chitosan and its derivatives such as COS. Chitin is insoluble in water and chitosan, in a form of chitin without or less acetyl group, is only soluble in weak acid. On the other hand, COS is readily soluble in water. A shorter chain length and the presence of free amino groups in D-glucosamine units in COS determine its solubility in water (Chasanah et al., 2011). In addition, COS has better bioactivity, such as an antibacterial (Sunardi, 2001; Wang et al., 2007), antifungi (No et al., 2007; Chasanah et al., 2013, antioxidant (Sun et al., 2007) and anticancer (Suzuki et al.,1986). Therefore, cos can be used as a component of functional food or medicine.

The previous research on the production of COS's by enzymatic degradation of chitosan resulted in high content of salt in the product, represented by ash content more than $2 \%$ (Chasanah et al., 2012). The presence of salt in chitooligosaccharide was accumulated from many chemical used in the production process. The addition of acid and base will produce salt. As required by US Food and Drug Administration (FDA), ash concentration more than $1 \%$ is not acceptable to be used as a component of functional food or pharmaceutical medicine, because it leads to several problems. Salt concentration is proportional to the ash concentration, the higher the ash concentration in sample, the higher also the salt concentration. The salt contained in the COS could interfere with the bioactivity of the COS (Chasanah et al., 2012). To remove salt from the production of COS, several desalting techniques such as dialysis and gel filtration techniques should be tested.

Dialysis is one of the common techniques used to separate salt content from a solution. The principle of dialysis is the migration of soluble content from high concentration solution to low concentration solution through a semi-permeable membrane by diffusion. The smaller sizes of molecules than the pore size of membrane are able to displace and reach equilibrium with the solvent outside the tube. In the equilibrium is state there are no molecules pass through the membrane, since the flow rate of the molecules in and out of the dialysis membrane is the same. Larger molecules which can not pass through the membrane will be held inside the dialysis tube.

The factors which influence the dialysis rate are the volume of solvent, composition of solvent, the number of solvent change, time, temperature, the size of particle and the pore size. Sample containing smaller particles than the pore size reach the equilibrium state faster than those which slightly smaller than the pore size. The other important factor in dialysis is time; sample with lower flow rate from the tube to the solvent need longer time to reach equilibrium than sample with higher flow rate.

Gel filtration chromatography is another technique to separates molecules based on their relative abilities to penetrate into an appropriate stationary phase or resin. The resin consists of very small, neutrally charged porous particles in an aqueous solution which has size-exclusion properties. The resin are packed into a column to be used for the separation of molecules during the chromatographic separation process. The pore sizes range of resin particles determine the size of molecules which are able to be separated. The average or maximum effective pore size defines the fractionation range or the limit of exclusion of the resin. The size of molecules smaller than the fractionation range is able to enter the pores of the resin, while the larger molecules are prohibited from entering the pores (Mc Cuen, 2009).

During the gel filtration chromatographic separation, small molecules in sample solution such as salts enter the pores of resin beads and forced to follow a non linear (circulated) path before exiting the beads. In contrast, large molecules flow around the resin beads and take a relatively direct flow through the column. As a consequence, small molecules taking much longer time to travel in the chromatographic column than large molecules and excluded later (Sauterer \& Jones, 2000).

Gel filtration chromatography is useful for many of the same purposes as dialysis, because both methods are based on similar ranges of molecular weight cutoff (MWCO) limits that exclude molecules based on size. Compared to dialysis, gel filtration has the advantage of speed (a few minutes vs. hours for dialysis), which is necessary in certain experimental situations.

The aim of this study was to remove salt from chitooligosaccharide with gel filtration chromatography and dialysis and to determine the best desalting technique by assessing the effectiveness of the salt removal and the variation of the product based on the degree of polymerization.

\section{Material and Methods}

\subsection{Material}

Materials used in this research were chitosan from crab shell with a degree of deacetylation (DD) of $42.35+1.65 \%$. The value of DD was low compared to 
commercial chitosan produced by SIGMA which has $85 \%$ of DD since the of DD was determined using different methods. When commercial chitosan was measured by FTIR the value of DD was $45.05+3.26 \%$ which is not significantly different with chitosan used in this experiment. Chitosanase was produced by Stenotrophomonas maltophilia KPU 2123 isolated from shrimp waste which is preserved in $-80^{\circ} \mathrm{C}$ freezer. Chemicals and microbiological media components used in this experiment were all in analytical grade unless describe specifically. Standard COS (1-6 unit) was from Seikagaku Corp. All laboratory experiments were done in triplicate and the value presented in this paper was the average of 3 series of data.

\subsection{Methods}

The research steps were consist of production of chitosanase enzyme from S. maltophilia KPU 2123 in $5 \mathrm{~L}$ fermentor, preparation of soluble chitosan, production of COS, desalting process using dialysis and gel filtration chromatography, and analysis of COS's product. Analysis of COS's including the salt content and the variance of oligomer products were conducted by MALDI-TOF.

\section{a. Production of chitosanase enzyme}

Production of chitosanase enzyme was following Pratitis (2006) and Chasanah et al. (2012) in 5 L fermentor with working volume of 3 liter of medium containing $1 \mathrm{~g} \mathrm{~K}_{2} \mathrm{HPO}_{4}, 0.1 \mathrm{~g} \mathrm{NaCl}, 7 \mathrm{~g}\left(\mathrm{NH}_{4}\right)_{2} \mathrm{SO}_{4}$,

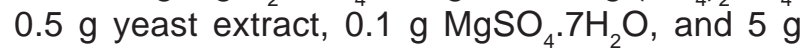
colloidal chitin per liter medium. After 120 hours of fermentation, the chitosanase enzyme was harvested by centrifugation at 8000 rpm, for 15 minutes at 4 ${ }^{\circ} \mathrm{C}$. The raw enzyme was concentrated by ultrafiltration by $10 x$ of volume using ultrafiltration membrane with 10 kD MWCO. The activity of chitosanase enzyme was measured by Schales method as described in Pratitis (2006).

\section{b. Preparation of soluble chitosan}

Soluble chitosan was prepared by dissolving of 5 $\mathrm{g}$ chitosan from crab shell in $1 \mathrm{M} \mathrm{CH}_{3} \mathrm{COOH}$ followed by addition of $200 \mathrm{ml}$ of aquadest and stirred at 100 $\mathrm{rpm}$. The $\mathrm{pH}$ of mixture was adjusted by addition of $1 \mathrm{M} \mathrm{CH}_{3} \mathrm{COONa}$ until $\mathrm{pH} 6$ and volume of mixture was made $500 \mathrm{ml}$ by addition of $0.05 \mathrm{M} \mathrm{CH}_{3} \mathrm{COONa}$. The insoluble material was separated by centrifugation at $10,000 \mathrm{rpm}, 4^{\circ} \mathrm{C}$ for 15 minutes and the clear solution of soluble chitosan was stored at $4^{\circ} \mathrm{C}$.

\section{c. Enzymatic production of chitooligosaccharide}

Production of COS's was carried out by mixing the soluble chitosan with chitosanase at concentration of $8 \mathrm{U} / \mathrm{g}$ chitosan. The mixture was incubated at room temperature for 16 hours followed by deactivation of enzyme at $100^{\circ} \mathrm{C}$ for 15 minutes.

\section{d. Desalination of chitooligosaccharides}

Two desalting techniques were applied i.e: dialysis and gelfiltration chromatography in order to remove the salt content of COS product. A dialysis tube with $10 \mathrm{kD}$ MWCO was used in this experiment. It was treated prior desalting by boiling the dialysis tube in solution of $10 \mathrm{mM} \mathrm{NaHCO}_{3} / 1 \mathrm{mM}$ EDTA for 3 hours followed by washing several times with aquadest and stored in $1 \mathrm{mM}$ EDTA solution for storage (Bollag et al., 1991). For the desalting process, the dialysis tube with sample was soaked in Mili-Qwater with constant stirring. Every 2 hours, the Mili-Q water was substituted with a new one.

Gel filtration chromatography was done in Akta Purifier FPLC (Fast Protein Liquid Chromatography) using HiPrep 26/10 column and milli-Q water as mobile phase. HiPrep desalting 26/10 was connected to Akta Purifier FPLC, in order to help the fractionation process. Every $5 \mathrm{ml}$ of eluate was automatically separated by Akta Purifier FPLC. Prior separated to release to the test tube, the sample was analyzed by spectrophotometer built in the Akta Purifier FPLC. Twelve $\mathrm{ml}$ of sample was injected with the flow rate of $1 \mathrm{ml} / \mathrm{min}$.

\section{e. Analysis of salt content and chitooligosaccharides}

Qualitative analysis of salt presence was identified using silver nitrate method, while the quantitative analysis was done with Volhard's method. Ash content was measured by putting a certain amount of COS in a furnace as describe in Sluiter et al. (2008).

Identification of COS's was conducted by TLC and MALDI-TOF. The TLC analysis was done by spotting $5 \mu$ of D-glucosamine standard, 1\% COS standard and samples on silica gel $60 \mathrm{~F}_{254}$. The mobile phase of TLC was 1 - propanol: water: $25 \%$ ammonia (7:2:1). The spot of TLC was visualized by spraying solution of $0.75 \mathrm{~g}$ of Ninhydrine in $50 \mathrm{ml}$ of 1 - butanol with addition of $1.5 \mathrm{ml}$ of acetic acid glacial prior to drying at $100{ }^{\circ} \mathrm{C}$ for 10 minutes. Analysis of COS product variance was done by MALDI-TOF.

\section{Results and Discussion}

Production of crude chitosanase enzyme and enzymatic bioconversion of chitosan into COS were conducted in the laboratory as described in material and methods section. 


\section{a. Production of crude chitosanase}

The activity and specific activity of crude chitosanase produced by S. maltophila was measured before and after ultrafiltration as presented in Table 1. The volume of the crude extract will be reduced by ten times after the ultrafiltration process. Ultrafiltration method was chosen because it can maintain the quality of enzyme, compare to concentrating the enzyme using chemicals which can harm the enzyme. Water and other proteins, which have a molecular size lower than $10 \mathrm{kDMWCO}$, will pass through the membrane. The chitosanase enzyme will not pass the membrane, therefore it will be concentrated. This will increase the activity of the enzyme because most of the residue which can lower its activity has been eliminated (Fawzya et al., 2009).

Table 1 shows that the total and specific activity of chitosanase increased 2 times and 6 times respectively after ultrafiltration process.

\section{b. Preparation of chitooligosaccharide}

The 1\% soluble chitosan used in the production was adjusted to $\mathrm{pH} 6$ as required by chitosanase enzyme for its optimum activity (Pratitis, 2006). When the $\mathrm{pH}$ is higher than 6 , then the soluble chitosan would be precipitated (Sunardi, 2001). Before hydrolysis, the solution had higher viscosity since the chitosan has large molecular mass, while after the hydrolysis process the viscosity reduced as presented in Table 2. The soluble chitosan was hydrolyzed by chitosanase which produce COS as the result. Chitooligosaccharide has lower molecular mass compare to chitosan, which also affect the viscosity. The decrease in viscosity showed that chitosan was already converted to COS's. The salt content of chitosan was increased after hydrolysis as the enzyme chitosanase was containing salt from the fermentation medium and contributing on the high salt content of COS product.

The presence of COS produced after enzymatic hydrolysis was identified for its degree of polymerization by using several analyses including TLC method and MALDI - TOF - MS. As shown in Figure 1, the COS's was absent in TLC result. It may be happen since the concentration of COS's was very low under the detection limit of TLC or the degree of polymerization of COS's produced by chitosanase in this experiment was high (more than six monomer) as the standard used in the TLC was range from monomeric to hexameric state.

Chitosan, being a base, can be solubilized in both inorganic and organic acids, forming salts with acids. The products of the hydrolysis reaction of chitosan salt are contributing in the salt content of its oligosaccharides (Jung \& Park, 2014). This means that a desalting process is necessary to obtain a pure oligosaccharide.

Standard COS with degree of polymerization of monomer to hexamer can be detected by TLC method as shown on Figure 1. The standard is resulting six spots which represent the degree of polymerization of monomer to hexamer. The glucosamine only shows one spot because it consists only of monomer. However, the results of TLC show that the COS with a degree of polymerization more than hexamer in the COS sample produced by enzymatic hydrolysis in the experiment were absent. It may be happened since the concentration of small size COS was lower than the limit detection of TLC. To overcome the limitation of TLC, more advance method which is MALDI - TOF - MS was used as presented in Figure 2 and 3.

The molecular weight glucosamine is $\mathbf{1 7 9 . 1 7}$ Daltons and acetyl group is 42 Daltons. Acetyl glucosamine as a monomer of COS was represented

Table 1. Activity and specific activity of chitosanase enzyme produced by S. maltophila KPU 2123

\begin{tabular}{lcc}
\hline Treatment & $\begin{array}{c}\text { Enzyme Activity } \\
(\mathrm{U} / \mathrm{ml})\end{array}$ & $\begin{array}{c}\text { Specific Activity } \\
(\mathrm{U} / \mathrm{mg})\end{array}$ \\
\hline Before Ultrafiltration & 0.080 & 0.265 \\
After Ultrafiltration & 0.183 & 1.488 \\
\hline
\end{tabular}

Table 2. Viscosity and salt content of chitosan before and after enzyme hydrolysis

\begin{tabular}{lcc}
\hline Sample & Viscosity (cp) & Salt Content (\%) \\
\hline Initial chitosan (before hydrolysis) & $128 \pm 0.5$ & 6.10 \\
After hydrolysis & $9 \pm 0.5$ & 10.97 \\
\hline
\end{tabular}




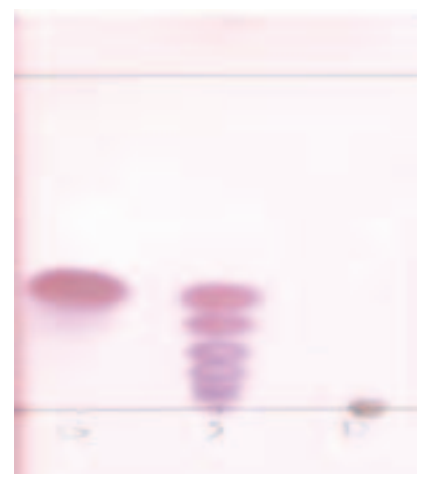

Figure 1. TLC result of Standard Glucosamine (G), standard of COS (S) and COS product (D).

by a peak with molecular weight of 215.12 Daltons which is the same with the data from chitooligosaccharide standard. The difference of molecular weight in COS produced are caused by different form of COS, some containing acetyl groups and some are without acetyl groups. From Figure 2, peak 1265.55 shows that there are larger COS such as dimer (413.52 Da) and trimer (611.25 Da) present in the standard.

Figure 3 shows the analysis result of COS produced. Peak 303.94 shows that there is trimer acetyl (579.86 Da). Peak 620.20 shows that there is trimer (537.14 Da). Peak 1330.19 shows there are heptamer (1253.27 Da) and heptamer acetyl (1297.16 Da). Peak 3534.49 shows that there is hexamer acetyl (1177.16 Da).

\section{c. Desalination study of chitooligosaccharides}

The qualitative salt analysis of COS desalted by dialysis showed that salt was not present in the sample. However, the quantitative salt analysis showed that there was small amount of salt remained in the dialysis tube. This phenomenon was happen since salt will pass through the membrane and some of them will also enter the dialysis tube back to reach equilibrium with solvent outside the dialysis tube. The concentration of salts in COS's after dialysis was decreased by $99.5 \%$ of initial concentration (Table 3).

From Table 3, it shows that $99 \%$ of the salt content was removed to the level of almost zero. The similar condition was happen on the ash content which decreased by $98 \%$. The dialysis process was able to meet the requirement for standard quality of commercial COS to be containing less than $1 \%$ of ash and salt as described in United States Food and Drug Administration (FDA).

Analysis of COS's variance in dialysis product was presented in Figure 4. From Figure 4, peak 361.94 shows that there is monomer (179.96 Da). Peak 401.26 shows that there are monomer (179.11 Da), dimer (359.23 Da) and dimer acetyl (400.252 Da).

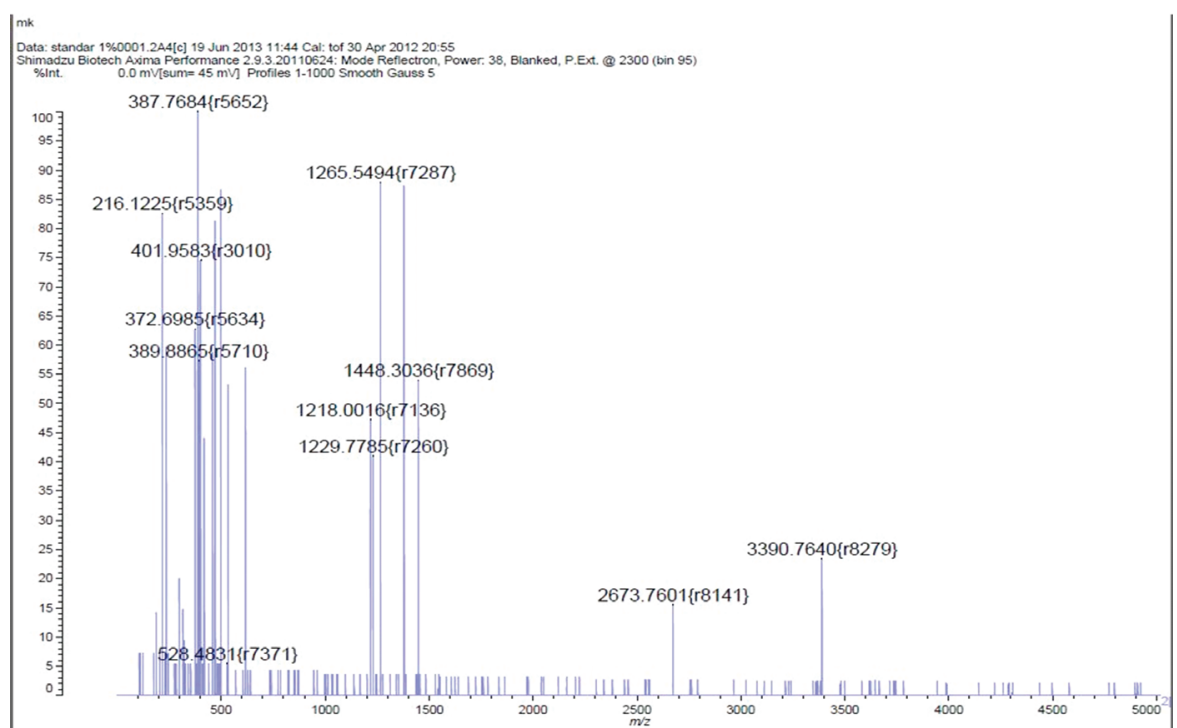

Figure 2. MALDI - TOF - MS analysis of chitooligosaccharide standard. 


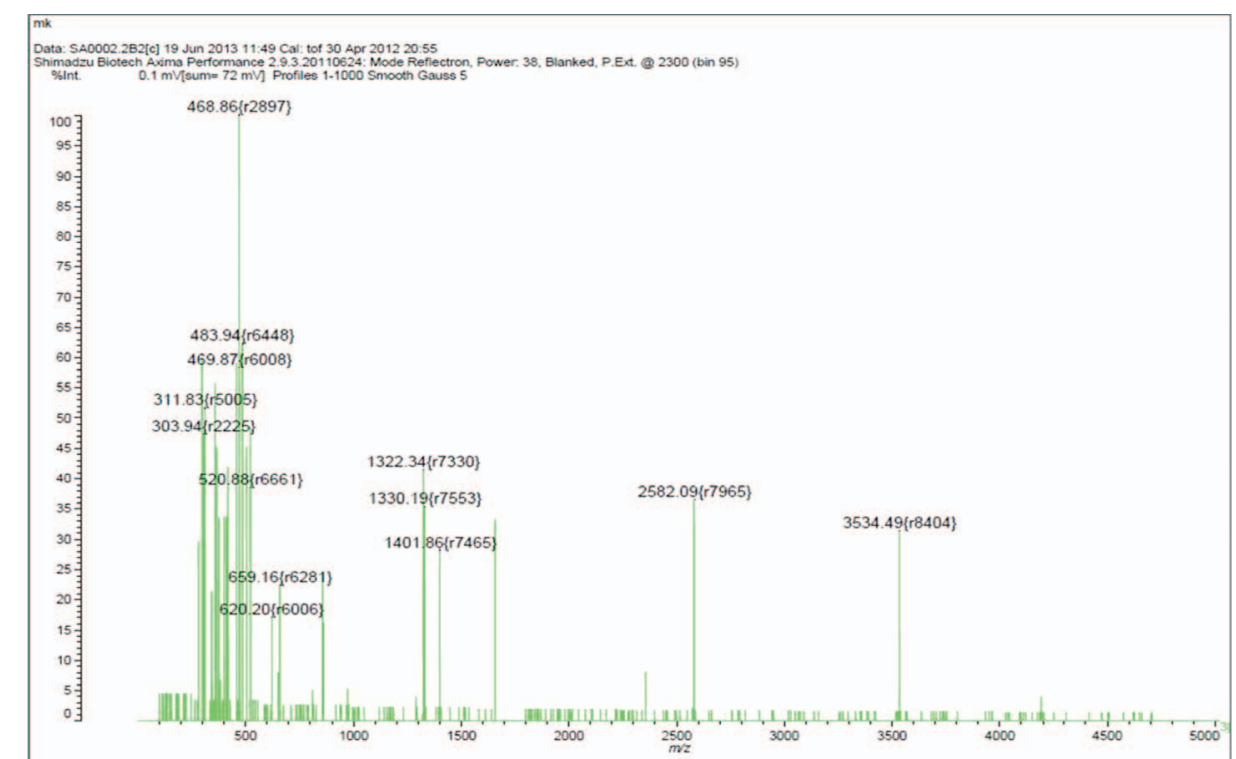

Figure 3. MALDI - TOF - MS analysis of chitooligosaccharide produced by enzymatic hydrolysis.

Peak 1819.19 shows that there is decamer (1796.20 Da). Peak 2532.15 shows that there are heptamer (1254.08 Da) and tetradecamer (2509.16 Da). Peak 2734 shows that there is pentamer (895.63 Da). Other peaks are identified as residue. because there are not similarity with the expected molecular weight calculation.

The spectophotometric profile of desalted COS by gel filtration chromatography is presented in Figure 5. From the result, it shows that there was a sharp peak from the eluate which was released to test tube $1-4$. There are also small peaks from the eluate which was released to test tube $5-8$ which overlap the peak from test tube $1-4$. Small peaks from the eluate of test tube $5-8$ are identified as residue, which is not COS. From this graph, it is concluded that there were two different substances separated by the hiPrep 26/10 desalting column.

The salt concentration analysis after gel filtration chromatography showed that all salt had been removed in the eluate $1-4$, and low concentration of salt still present in eluate 5 - 8 sample (Table 4 ).
Salt as smaller molecule penetrate inside the pore of the beads which make them filtered more slowly compare to bigger size molecules as COS which will pass the beads and flow more quickly through the space between the beads. Consequently, salt can be separated from COS which is eluted earlier (fraction 1-4), while salt was eluted latter in the fraction or test tube 5-8.

The ash content of COS desalted by gel filtration chromatography also meets the requirement of the commercial COS. The variance of COS's product after gel filtration chromatography was analyzed by MALDI - TOF - MS. The results were presented in Figure 6 and Table 5.

The composition of COS's after dialysis were not as complete as gel filtration process. Some small size COS were missing from dialysis product which were present in gel filtration results. It was possible that higher molecular weight cut off (MWCO) of dialysis membrane used in the experiment causing molecules with molecular weight less than $10 \mathrm{kD}$ washed out. To produce more variation of COS's, smaller MWCO membrane must be applied.

Table 3. Ash content and salt concentration of COS after dialysis

\begin{tabular}{lcc}
\hline \multicolumn{1}{c}{ Sample } & Ash Content (\%) & Salt Concentration (\%) \\
\hline $\begin{array}{l}\text { Initial chitooligosaccharide } \\
\text { (before dialysis) }\end{array}$ & 1.99 & 0.2181 \\
After dialysis & 0.04 & 0.0001 \\
\hline
\end{tabular}




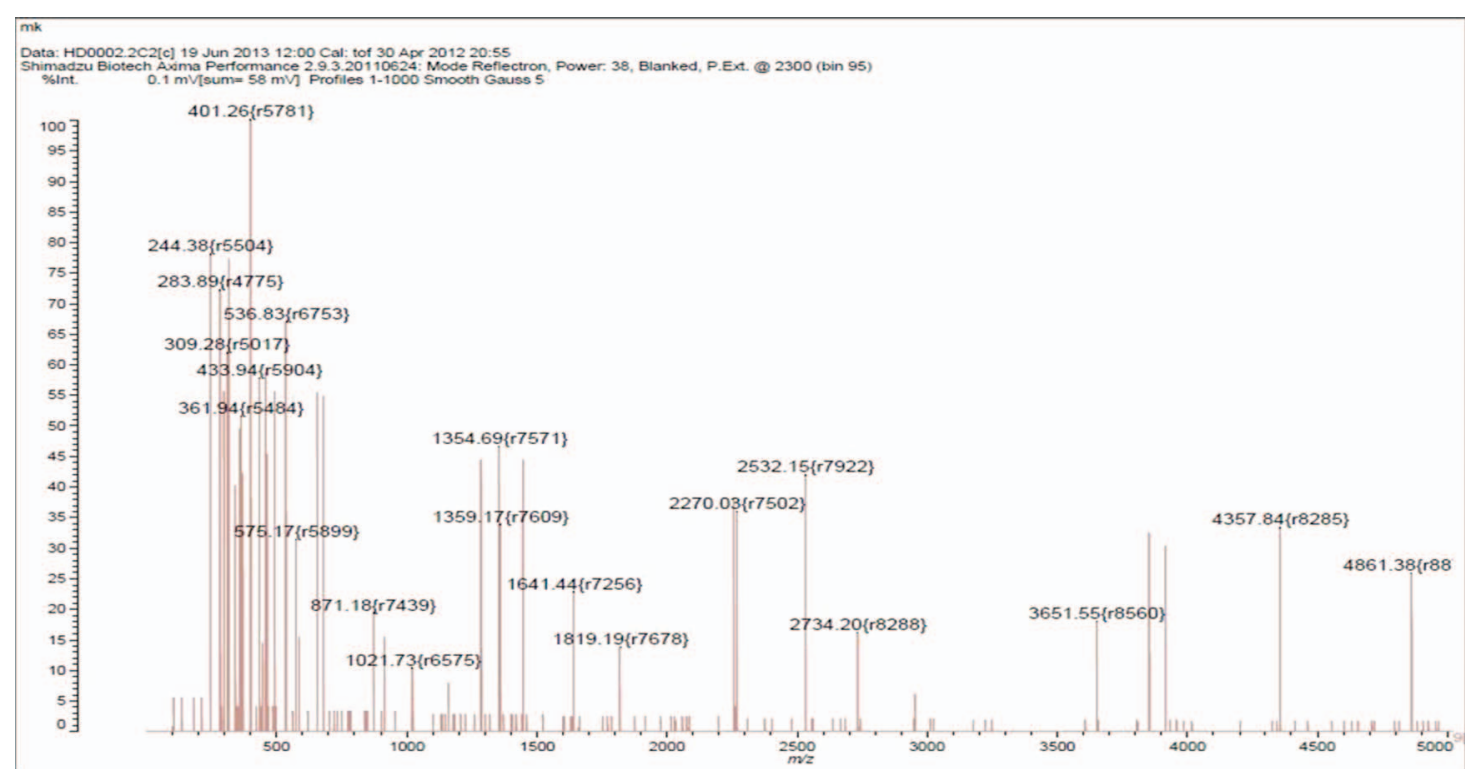

Figure 4. MALDI - TOF - MS analysis of dialysis result.

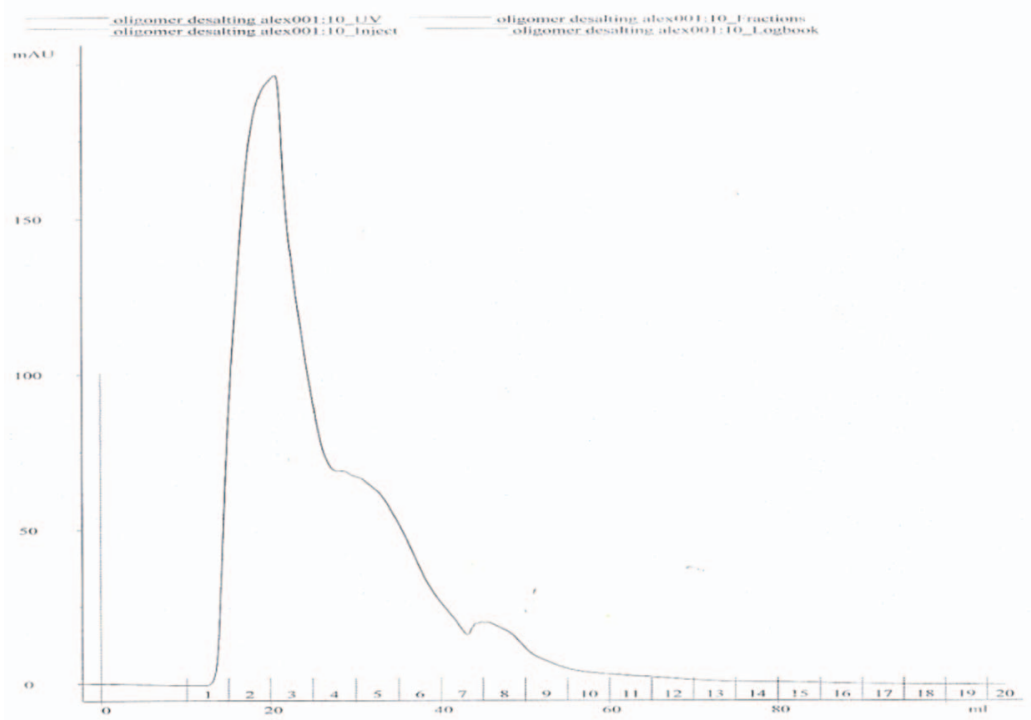

Figure 5. Spectrophotometry profile of desalted chitooligosaccharides with gel filtration chromatography.

Table 4. Ash content and salt concentration of COS after gel filtration chromatography

\begin{tabular}{ccc}
\hline Sample & Ash Content (\%) & Salt Concentration in ash (\%) \\
\hline Initial Chitooligosaccharide & & \\
(before gel filtration & 1.99 & 0.2181 \\
chromatography) & & \\
Eluate 1 - 4 & 0.00 & 0.0000 \\
Eluate 5 -8 & 0.41 & 0.0136 \\
\hline
\end{tabular}




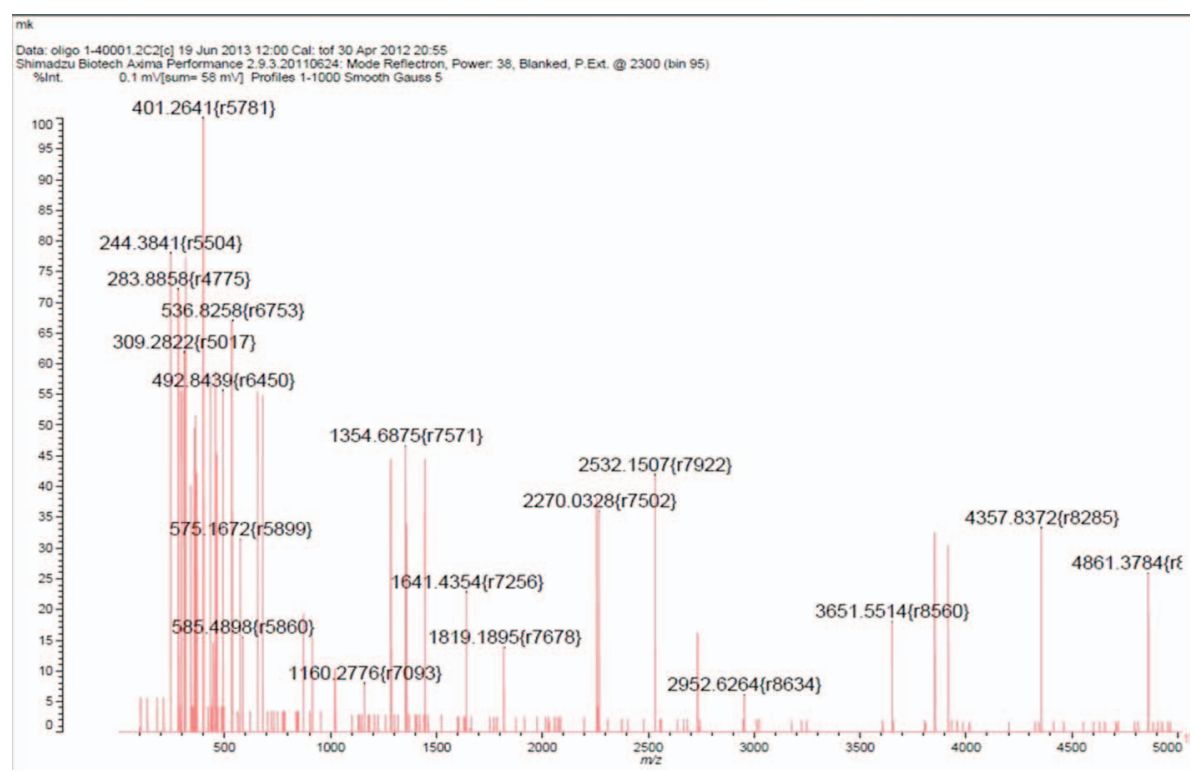

Figure 6. MALDI - TOF - MS analysis of gel filtration chromatography result.

Table 5. Variance of COS product with different degree of polymerization after Gel Filtration Chromatography

\begin{tabular}{clc}
\hline No & \multicolumn{1}{c}{ cos } & Molecular weight (Dalton) \\
\hline 1 & monomer & 179.11 \\
2 & dimer & 359.226 \\
3 & dimer acetyl & 400.252 \\
4 & trimer & 538.11 \\
5 & hexamer acetyl & 1118.25 \\
6 & heptamer & 1254.08 \\
7 & octamer & 1434.28 \\
8 & octamer acetyl & 1475.31 \\
9 & decamer & 1796.20 \\
10 & tetradecamer & 2509.16 \\
11 & hexadecamer acetyl & 2907.66 \\
\hline
\end{tabular}

Table 6. Effectiveness of salt removal and chitooligosaccharide variance from desalting process using dialysis and gel filtration techniques

\begin{tabular}{lccl}
\hline Desalting Techniques & Ash Content (\%) & Salt Removed (\%) & \multicolumn{1}{c}{ cos occurrence } \\
\hline Dialysis & 0.04 & 99.95 & $\begin{array}{l}\text { monomer, dimer, dimer acetyl, } \\
\text { pentamer, heptamer, decamer, } \\
\text { tetradecamer }\end{array}$ \\
& & & $\begin{array}{l}\text { monomer, dimer, dimer acetyl, } \\
\text { trimer, hexamer acetyl, } \\
\text { heptamer, octamer, octamer } \\
\text { acetyl, decamer, tetradecamer, } \\
\text { Chromatography }\end{array}$ \\
& 0.00 & 100 & \\
& & \\
& & \\
& &
\end{tabular}


Comparison of each desalting technique on final salt concentration and the effectiveness of salt removal were presented in Table 6.

From Table 6, it shows that the COS with various degree of polymerization occurrence is more complete in gel filtration chromatography. The composition of COS's after dialysis were poorer compared to gel filtration process. Application of dialysis membrane of $10 \mathrm{kD}$ MWCO may contribute to this result, as more products were washed out during the process of dialysis.

\section{Conclusion}

Gel filtration chromatography is the best method to remove salt from COS production process. Gel filtration chromatography with matrix of Sephadex G -25 superfine can separate all of the salt from COS and producing COS with various degree of polymerization occurred more completely.

Dialysis technique was also able to remove most of the salt from COS. However, COS with various degree of polymerization occurred less completely. Lower MWCO dialysis membrane are needed to obtain better COS's product.

MALDI - TOF - MS is able to identify the presence of COS with various degree of polymerization. It also could detect the presence of COS with degree of polymerization monomer to hexamer, even if the concentration is low.

\section{References}

Chasanah, E., Patantis, G., Zilda, D. S., Ali, M., \& Risjani, Y. (2011). Purification and characterization of Aeromonas media KLU 11.16 chitosanase isolated from shrimp waste. J.Coastal Dev., 15(1), 104-113.

Chasanah, E., Fawzya, Y. N., Poernomo, A., Martosuyono, P., Patantis, G. \& A. Pratitis. (2012). Laporan akhir Penelitian Pemanfaatan Mikroba Penghasil Enzim Potensial untuk Pengembangan Produk Perikanan. Balai Besar Penelitian dan Pengembangan Pengolahan Produk dan Bioteknologi Kelautan dan Perikanan, Jakarta. pp. 23-42.

Chasanah, E., Fawzya, Y. N., Karmawidjaja, F. A., \& Maruli, S. (2013). Bioaktivitas Kitooligosakarida yang Diproduksi dari Kitosan Menggunakan Kitosanase Microminospora T5a1 sebagai Antikapang. J. Pascapanen dan Bioteknologi Kelautan dan Perikanan, 8(1), 65-72.
Fawzya, Y. N., Endah, H., \& Pratitis, A. (2009). Produksi dan aplikasi enzim kitosanase dari bakteri asal terasi untuk pembuatan oligomer kitosan.Prosiding Seminar Nasional Kelautan V. Universitas Hang Tuah, Surabaya 23 April 2009: II-413 - II-418

Jung, W. J. \& Park, R.D. (2014). Bioproduction of Chitooligosaccharides: Present and Perspectives. Mar. Drugs.,12(11), 5328-5356.

Kim, S. K. (2011). Chitin, Chitosan and Their Derivatives: Biological Activities and Applications. Boca Raton, FL, USA : Taylor and Francis Group. pp. 447-461

Mahata, M. E., Dharma, A., Ryanto, I. , \& Rizal, Y. (2008). Effect of substituting shrimp waste hydrolysate of Peneus merguensis for fish meal in broiler. Journal of Nutrition, 7 (6), 806-810.

McCuen, B. R. 2009. Chromatography methods. J. of Validation Technol., 15(3), 17-22.

No, H. K., Meyers, S.P., Prinyawiwatkul, W., \& Xu, Z. (2007). Applications of chitosan for improvement ofquality and shelf life of foods : A review. J. Food Sci.. 72(5), 87-100.

Pratitis, A. (2006). Isolasi dan Karakterisasi Enzim Kitosanase dari Bakteri Laut yang Berasosiasi dengan Spons. Thesis. Department Fishery and Marine Sciences. Institut Pertanian Bogor, Bogor, Indonesia.

Sauterer, R. A. \& Jones, J. (2000). A rapid, simple \& inexpensive experiment in gel filtration chromatography. J. of the American Biol. Teacher, 62(8), 602-608.

Siringoringo, L. (2011). Proses Pemisahan Kandungan untuk Mendapatkan Chitosan dari Limbah Udang. Harian Kontan 23 Juli 2011: 18

Sluiter, A., Hames, B., Ruiz, R., Scarlata, C., Sluiter, J., \& Templeton, D. (2008). Determination of Ash in Biomass. Laboratory Analytical Procedure (LAP). Technical Report NREL/TP-510-42622: 1-8

Sun, T., Zhou, D. X., Xie, J. L., \& Mao, F. (2007). Preparation of chitosan oligomers and their antioxidant activity. J. Eur. Food Res. Technol., 225 (6), 451-456.

Sunardi. (2001). Isolasi Kitosan dan Aplikasinya Sebagai Zat Antibakteri dengan Metode Total Plate Count (TPC). Thesis. Departemen IImu dan Teknologi Kelautan. Institut Pertanian Bogor, Bogor, Indonesia. pp. 47-56

Suzuki, K., Mikami, T. , Okawa, Y., Tokoro, A., Suzuki, S., \& Suzuki, M. (1986). Antitumor effect of hexa-Nacetylchitohexaose and chitohexaose. J. Carbohydrate Res., 27(151), 403-408. 
Squalen Bulletin of Marine \& Fisheries Postharvest \& Biotechnology, 9 (3), 2014, 127-136

Wang, Y., Zhou, P., Yu, J., Pan, X., Wang, P., Lan, W., \&

Tao, S. (2007). Antimicrobial effect of chitooligosaccharides produced by chitosanase from pseudomonas cuy 8. J. Clin. Nutr., 16(1), 174-177. 